DIANA SORIĆ

UDC: $821.124(497.5)-6.09$

Sveučilište u Zadru

disoric@unizd.hr

MAJA CIFREK

Samostalni istraživač

majacifrek@gmail.com

\title{
DVA UTJEŠNA PISMA ANTUNA VRANČIĆA (1504.-1573.)
}

\begin{abstract}
Sažetak. - Konzolacija kao književni fenomen odnosi se na tekst napisan nakon nečije smrti, namijenjen ožalošćenoj osobi s ciljem ublažavanja ili prevladavanja boli. Retorika i različiti filozofski pravci izvršili su značajan utjecaj na konzolaciju, a pojavom kršćanstva došlo je do spajanja kršćanskih i poganskih motiva. Utješna su pisma bila veoma popularna u razdoblju humanizma te su njihovi autori često posezali za antičkim uzorima. U ovom se radu analiziraju dva utješna pisma, koja je šibenski humanist i latinist Antun Vrančić (1504.-1573.) uputio dvojici prijatelja s namjerom ublažavanja njihove tuge povodom smrti njihovih očeva. Nakon kratkog pregleda konzolacijske tradicije, istražuje se mogući utjecaj antičke konzolacijske topike te dvaju humanističkih epistolografskih priručnika, Erazma Roterdamskog (1469.-1536.) i Franje Nigera (1452.-?), na topiku koju pronalazimo u Vrančićevim pismima. U prilogu na kraju rada donosi se kritičko izdanje Vrančićevih pisama priređeno prema autografima iz budimpeštanske knjižnice Széchényi.
\end{abstract}

Ključne riječi. - konzolacija, Antun Vrančić, utješna pisma, Erazmo Roterdamski, Franjo Niger.

\section{Uvod}

Pod pojmom consolatio podrazumijeva se tekst napisan neposredno nakon nečije smrti, upućen jednom ili više adresata, s ciljem ublažavanja ili prevladavanja boli. Potreba za sastavljanjem takvih utješnih tekstova postoji još od najranijih vremena, a njihovu temeljnu strukturu oblikovali su grčki i rimski autori. Pravila koja su oni postavili primjenjivala su se, uz određene preinake i proširenja, u srednjem vijeku te u razdoblju humanizma i renesanse. Konzolacijska su djela pisana u raznim literarnim oblicima, a neka od poznatijih i danas sačuvanih, sastavljena su u obliku pisama. Okosnica su ovoga rada dva utješna pisma Antuna Vrančića, koja je poslao dvojici prijatelja, Mlečaninu Francescu Capellu i Poljaku Ivanu Boneru, s čijim je obiteljima održavao bliske odnose. Vrančićeva se pisma analiziraju kao ostvarenje konzolacijskog žanra te se nastoji utvrditi mogući utjecaj konzola- 
cijske topike te dvaju humanističkih epistolografskih priručnika, Erazma Roterdamskog i Franje Nigera.

\section{Kratak osvrt na konzolacijsku tradiciju}

\subsection{Antička konzolacija}

Temeljnu su strukturu utješnih tekstova oblikovali antički autori, a razvoj konzolacije kao književne vrste uslijedio je nakon što je tema utjehe doživjela razradbu unutar filozofije. ${ }^{2}$ Osim filozofije i retorika je bila veoma važna za razvoj konzolacije jer je autorima utješnih tekstova omogućila sredstva jezične formulacije i metodičke grupacije konzolacijskih teza. Poseban je utjecaj izvršila dijatriba kao retoričkofilozofski oblik izlaganja kojeg su zastupali cinici, a njegove karakteristike su jednostavna stilska sredstva, paralelizam, antiteze, igra riječi i razgovor s fiktivnim partnerom. Prema stoicima duševna se patnja treba razmatrati u okviru učenja o afektima i strastima. Oni oštro osuđuju sve afekte, a posebno duševnu bol. Mišljenje tugujućeg, da je zbog gubitka pogođen zlom, treba razotkriti kao lažno i loše, prije nego što ono postane čvrsto uvjerenje. To se postiže pokudom nepoželjnog ponašanja i isticanjem ljudi, koji su istu sudbinu uzornije podnijeli. Na taj način treba tugujući postupno spoznati da prividna veličina zla ovisi o njegovom subjektivnom umišljanju. Tada se može otkloniti i pogrešno vjerovanje o opravdanosti i obvezi predavanja tuzi i boli. ${ }^{3}$ Akademičar Krantor ${ }^{4}$ prvi je u svom djelu $\Pi \varepsilon \rho i \pi \varepsilon ́ v \theta o v \varsigma$ sistematizirao argumente za konzolaciju. To je djelo pisano za Hipokla povodom smrti njegove djece i stoljećima je bilo uzor autorima konzolacija. ${ }^{5}$ Veći je dio konzolacijskih djela nažalost izgubljen, poput Krantorova, koje je bilo vrlo hvaljeno. U njemu se tuga ne obrađuje kao sramotna emocija, već kao prirodni impuls, koji jedino zahtijeva da bude držan pod kontrolom. Konzolacijske riječi ujedinjuju šarm pjesnika, ozbiljnost filozofa i veličanstvenost govornika. ${ }^{6}$

Latinska konzolacija kao formalni literarni oblik nije postojala prije Cicerona. ${ }^{7}$ Najveći uzor bio mu je Krantor. Slijedio je njegove konzolacijske argumente, ali je pokazao originalnost razvivši dalje neke od tih argumenata. ${ }^{8}$ Ciceron se u svom djelu De consolatione temeljito posvetio problemu tuge i utjehe, nakon što mu je umrla kći Tulija. To je jedan od prvih utješnih tekstova na latinskom u kojem je tema

${ }^{1}$ O Erazmovu i Nigerovu utjecaju na prigodna pisma Antuna Vrančića vidi: Sorić 2017: 1-8.

${ }^{2}$ Usp. Brannen 1948: 1-2.

${ }^{3}$ Usp. Schaeben 2002: 5-22.

${ }^{4}$ Grčki filozof (Soli u Ciliciji, IV. st. pr. Kr. - ?, oko 276. pr. Kr.).

${ }^{5}$ Usp. Brannen 1948: 3-6.

${ }^{6}$ Usp. Moran 1917: 7-8.

${ }^{7}$ Brannen 1948: 6 .

${ }^{8}$ Brannen 1948: 41. 
utjehe sustavno obrađena s filozofskog stajališta. Nešto kasnije obradio je ponovno konzolacijsku temu u obliku dijaloga u djelu Disputationes Tusculanae, gdje se u zaključku diskusije nude dva gledišta: Ili nakon smrti ne postoji ništa ili postoji sretan nastavak života. U oba slučaja smrt nije kazna, već oslobođenje. ${ }^{9}$ Ciceron inače zastupa stoičko učenje, prema kojemu uzrok patnje, kao i svih afekata, leži u našem pogrešnom subjektivnom mišljenju. Po njemu je učinkovit lijek za ublažavanje patnje spoznaja da su drugi ljudi već preživjeli slična zla. ${ }^{10}$ Smatra da su mudrost i promišljanje učinkovitiji u ublažavanju tuge od samog vremena. Međutim, i sam iskusni konzolator, priznaje svom prijatelju Atiku, da mu svi utješni razlozi, koje su razvili filozofi, ne mogu pomoći prevladati bol nakon smrti voljene kćeri Tulije. ${ }^{11}$

Nakon Cicerona konzolaciju su dalje razvijali mnogi rimski pisci poput Statija, Boetija, Plinija Mlađeg i Seneke pa je tijekom tog razdoblja poprimala sve ustaljeniji oblik sa sličnim sadržajem i standardiziranom strukturom. Od svih konzolacijskih djela rimskih autora Senekino je djelo Ad matrem Helviam de consolatione najbliže konvencijama tog žanra. Seneka podsjeća majku na sve patnje koje je prošla zbog njegova progonstva, a koje su je naučile da bude hrabra u prevladavanju žaljenja. U središnjem dijelu Seneka smatra da može nadvladati Helvijinu žalost, ako najprije dokaže da on sam nije nesretan, a zatim da majčina nesreća nije ozbiljna. Zaključuje da je glavni razlog njezine tuge bol zbog razdvajanja. ${ }^{12}$ Senekina su djela određena stoičkim učenjem, koje je ipak ponešto ublaženo. On naime priznaje da logos ne upravlja potpuno čovjekom, već i emocije imaju određeni udio. ${ }^{3}$ Također smatra, budući da su utješni razlozi ograničeni, da se sve vezano za utjehu može pronaći u starijoj književnosti. Na konzolatoru je da procijeni kada je potrebno primijeniti određeni argument $\mathrm{i}$ određenu metodu, kao i odrediti redoslijed pojedinih utješnih razloga na temelju dubokog poznavanja starije književnosti. Treba također paziti i na podrijetlo, status, spol, starost i stupanj obrazovanosti adresata. $^{14}$

Mary Evaristus Moran je u svojoj disertaciji The consolations of death in ancient Greek literature prikupila i klasificirala konzolacijske topose, koji su zastupljeni u književnim djelima grčkih pisaca. Ona razlikuje jedanaest toposa utjehe nakon nečije smrti. Sažet pregled tih toposa donosimo u nastavku.

\footnotetext{
${ }^{9}$ Usp. Schaeben 2002: 5-22.

${ }^{10}$ Usp. Crepajac 1974: XX-XXVI.

${ }^{11}$ Usp. Zimmermann 2008: 389-390.

${ }^{12}$ Usp. Brannen 1948: 7-10.

${ }^{13}$ Usp. Schaeben 2002: 5-22.

${ }^{14}$ Usp. Zimmermann 2008: 389-390.
} 


\subsection{Konzolacijska topika}

Konzolacijska je topika $\mathrm{u}$ antici bila podijeljena u jedanaest kategorija, od kojih se neke međusobno isprepliću. Prvi se topos odnosio na neizbježnost smrti, koja ne može doći prije vremena kojeg su odredili bogovi. Drugi topos govori o tome da su i drugi prije nas morali umrijeti te da su i bolji ljudi umrli. Treći topos objašnjava smrt kao plaćanje duga prirodi. Četvrti topos ističe da smrt nije neočekivana te da će promišljanja o smrti umanjiti strahove i suze zbog smrti. Peti topos zastupa stajalište da je smrt oslobođenje od tuge te da smrt nije zlo, već blagoslov i lijek za sva zla te se uspoređuje s mirnim snom. Život se smatra hodočašćem, a smrt krajem putovanja, odnosno lukom koja pruža utočište od životnih teškoća. Šesti topos govori o tome da je smrt prije tuge smatrana blagoslovom. Rana smrt, tj. smrt prije vremena najviše se oplakuje. Najvećom se nesrećom smatra umrijeti ne dočekavši vjenčanje ili djecu, a za roditelje da nadžive svoju djecu. Međutim, život pun vrlina je bolji od najdužeg života. Sedmi topos ističe da mrtvi ne pate zbog gubitka životnih blagodati. Osmi topos se bavi izražavanjem tuge. Ono može donijeti olakšanje, no u tome ne treba pretjerivati. Prekomjerno žaljenje je beskorisno jer se suzama ne mogu vratiti pokojnici. Otvoreno izražavanje žaljenja nije dostojno časti plemenitog čovjeka i pokojnici ne bi željeli vidjeti da njihovi voljeni tuguju. Deveti topos naglašava da sjećanje na prošle radosti pomaže ublažiti tugu. Također se treba fokusirati na blagoslove koje trenutno uživamo. Vrijeme ima utjecaj na tugu i ublažit će i najveću patnju. Deseti topos razmatra besmrtnost duše. Posljednji topos bavi se slavom nakon smrti. Umrijeti u trenutku uspjeha ili prilikom obavljanja plemenite dužnosti smatralo se prikladnim završetkom života. Posebno se slavila smrt za domovinu, koja se smatrala moralnom dužnošću. Nada u vječno sjećanje nakoknađuje gubitak života. Te misli su naročito zastupljene u pogrebnim govorima. Svi ovi argumenti konzolacije teže prvenstveno stanju rezignacije $s$ onim što je neizbježno tj. sa smrću, nego pravoj utjesi u trenucima tuge. ${ }^{15}$

\subsection{Srednjovjekovna konzolacija}

Propašću Rimskog Carstva i nastankom kršćanske literature nije nestala konzolacija kao vrsta, već je vjerom u uskrsnuće mrtvih došlo do njezine promjene i proširenja. Razlikuje se ljudska i Božja utjeha, a smrt se promatra kao preduvjet za vječni život u Božjoj savršenosti. $\mathrm{Za}$ vrijeme patrističkog razdoblja koristila su se sredstva dijatribe i naglašavao se ideal strpljivosti, povezan s pesimističnom predodžbom ovog svijeta. ${ }^{16}$ Smatralo se da slaba utjeha pomoću prisutnosti ili ra-

\footnotetext{
${ }^{15}$ Usp. Moran 1917: 10-83.

${ }^{16}$ Usp. Schaeben 2002: 5-22.
} 
zumskih metoda jednog čovjeka može bol samo ublažiti i učiniti podnošljivijom. Nasuprot tome, jedino Božja okrjepa može potpuno ukloniti bol. U uputama o postupcima kod tješenja prevladavaju ponajviše preporuke suosjećanja i takta. Plakati s onima koji plaču ogleda se kao prilagođavanje na situaciju, a ravnodušnost tješitelja uvećava bol tugujućeg. Bol se ne može spoznati na drugačiji način nego u suosjećanju. ${ }^{17}$ Kritiziranje ženske i dječačke slabosti, poticaj na uzornu postojanost, podsjećanje na službene časti i obveze podupiru također i kršćansku preporuku zaboravljanja na vlastite potrebe i podređivanje zajednici. Nije tuga kao neizbježan osjećaj tugujućeg sramota, već njezino isticanje kao gubitak svega i prekid s društvenom stvarnošću. ${ }^{1}$

U srednjem se vijeku konzolacija često afirmirala u epistolografiji. Takva su utješna pisama najčešće započinjala izrazom suosjećanja i jamstva u naklonost, čime se uspostavlja kontakt s adresatom, pristankom na tugu, koja se u nastavku teksta treba ublažiti ili otkloniti. Nakon središnjeg dijela pisma u kojem se naizmjenice nižu pohvale i tužaljke, na način da se hvali hrabrost tugujućeg te se ostavlja dojam da je daljnja utjeha suvišna, slijedi zaključak kada se autor pisma usmjerava na najvažniji argument utjehe. Preporuča se ili usmjeravanje na božansko ili povratak iz tuge prema obvezama svakodnevnog života. Konačno, sam tješitelj može pružiti oslonac tugujućem i biti zamjena za umrlog. Tim motivom može završavati prijateljsko pismo. ${ }^{19}$

Osim utješnih pisama, postojali su različiti tekstovi konzolacijskog karaktera, kao što su izvještaji o smrti, osmrtnice, molba za sjećanje na mrtve, oproštajna pisma u kojima se unaprijed tješi zbog moguće skore smrti osobe itd. Naziv consolatio višeznačno se upotrebljavao. Nije se odnosio samo na utješne tekstove povodom smrti, iako oni po antičkom određenju predstavljaju tu vrstu u stvarnom značenju, već consolatio može označavati svaku vrstu duhovnog podizanja. Specifične oznake za utješne tekstove povodom smrti su: consolatio de (super) morte, consolatio mortuorum (defunctorum), dok se antički pojam consolatio mortis rjeđe upotrebljavao. Čitava srednjovjekovna utješna i naricateljska kultura odlikovala se po simplicitas i silentium te odbijanjem superfluitas i verba delicata. ${ }^{20}$

\subsection{Humanistička konzolacija}

Humanistička se konzolacija može smatrati eklektičnim spojem raznih filozofskih stajališta jer se autori nisu fokusirali na samo jedan, već su često u konzolacijske tekstove umetali elemente različitih filozofskih pravaca. Ciceronova su djela koristili kao model za taj eklektični način razmišljanja te su prihvaćali njegovo vjerovanje da je filo-

\footnotetext{
${ }^{17}$ Usp. von Moos 1971: 59-70.

${ }^{18}$ Usp. von Moos 1971: 450-451.

${ }^{19}$ Usp. von Moos 1971: 48-51.

${ }^{20}$ Usp. von Moos 1971: 39-46.
} 
zofija lijek za dušu i izbavitelj od anksioznosti, čežnje i straha. Osim toga, mnogi su humanisti naglašavali Ciceronov stav da su ljudske osobine poput aktivnosti, mudrosti, proučavanja i sjećanja esencijalne za obuzdavanje tuge te da istovremeno potiču težnju za časnim životom. Također su uzimali u obzir kršćansku konzolacijsku tradiciju te su se trudili postići ravnotežu između kršćanske i antičke poganske tradicije. Većina humanista bili su kršćani te su našli način da uklope vjeru u svoja djela. ${ }^{21}$

Humanističke interpretacije postupanja s tugom naglašavale su važnost sposobnosti pojedinca da prevlada nevolje, no razlikovale su se po načinu kojim se postiže otpuštanje tuge. Platonisti su smatrali da je besmrtnost duše i njezino odvajanje od tijela temelj za idealizam onih koji su na drugom svijetu. Stoici su pak naglašavali važnost gotovo potpune neosjetljivosti i ravnodušnosti na vanjske utjecaje te su smatrali da je to adekvatna reakcija na smrt bližnjih. Peripatetici ili aristotelovci su smatrali da smrt i tugovanje imaju neumitan utjecaj na ljudsku staloženost. Proučavanje i prestanak tugovanja tako vode čovjeka do potrage za istinskom srećom. Unatoč razlikama, svaki od tih filozofskih pravaca naglašavao je potrebu da ožalošćeni ode korak dalje od samog osjećaja tuge. ${ }^{22}$

Budući da su u fokusu ovog rada dva konzolacijska teksta napisana u formi pisma, u nastavku će se predstaviti dva humanistička epistolografska priručnika, koja su služila kao pomoć pri pisanju pisama humanističkim autorima.

\subsubsection{Konzolacija kod Erazma i Nigera}

Jedan od najutjecajnijih epistolografskih priručnika u humaniz$\mathrm{mu}$ bio je Opus de conscribendis epistolis Erazma Roterdamskog. ${ }^{23}$ To je djelo doživjelo više od pedeset izdanja. Gotovo isto toliko se puta tiskao i Modus epistolandi Franje Nigera. ${ }^{24}$ Nigerova je popularnost bila tako velika da je od 1488. do 1573. godine djelo doživjelo oko pedeset i devet izdanja. ${ }^{25} \mathrm{U}$ tim su se priručnicima davale upute potencijalnim sastavljačima pisama o tome kako treba pisati pojedine vrste pisama te na što sve treba autor pisma paziti. S obzirom na to da je u humanizmu epistolografija kao književni žanr bila izuzetno popularna, za očekivati je da su humanisti, među koje spada i Vrančić, rado kon-

${ }^{21}$ Usp. Tworek 2004: 27-34.

${ }^{22}$ Usp. Tworek 2004: 27-34.

${ }^{23}$ Erazmo Roterdamski (lat. Erasmus Roterodamus, Rotterdam, 28. X. 1466. ili 1469. Basel, 12. VII. 1536.), pravim imenom Geert Geerts, bio je nizozemski humanist, filozof i filolog.

${ }^{24}$ Franjo Niger (lat. Franciscus Niger, Venecija, 17. IV. 1452. - Italija, nakon 1523.). hrvatski je humanist i polihistor koji se bavio retorikom, filozofijom, pravom, teologijom, glazbom te jezicima.

${ }^{25}$ Usp. Jurić 1975: 285-296. 
zultirali takve priručnike. Inače, nakon 1530. godine na Krakovskom sveučilištu, gdje se Vrančić školovao, Erazmov je priručnik spadao u obveznu literaturu, a odlukom Akademije 1538. godine i Nigerov je uvršten u studijski curriculum. ${ }^{26}$

Erazmo je u svome djelu odredio tri pristupa kojima možemo ostvariti konzolaciju. Prvi je otvoren i direktan pristup kojim pokazujemo da nema smisla tugovati budući da mudraca može pogoditi samo gubitak časti, a ne nekakav vanjski faktor. Na taj se način obraćamo filozofu ili čovjeku snažnog karaktera. Drugi je pristup indirektan i koristi se kada se obraćamo osobi slabijeg karaktera te kada je rana previše ozbiljna ili svježa. Diskretan je pristup treći način, koji se upotrebljava kod obraćanja osobama koje potiskuju čak i velike boli. Erazmo opisuje i značajke konzolacije koje treba imati na umu prilikom njezina sastavljanja. Odmah na početku pisma morali bismo preuzeti na sebe osjećaje adresata, tj. treba se uživiti u njegovo stanje i pisati takvim jezikom, da se čini kao da izražavanjem tuge ublažavamo vlastitu bol, a ne adresatovu. Također bismo trebali izraziti sumnju u našu sposobnost pružanja utjehe jer osjećamo jednaku tugu kao i osoba kojoj moramo pružiti utjehu. Uzroke boli bilo bi dobro preuveličati, ne samo zbog same nesreće, već i zbog toga što tako nešto adresat nije zaslužio. Nakon toga treba pokušati umanjiti veličinu nesreće, vjerujući da će biti kratkog trajanja. Ako se pak čini da će nesreća duže trajati, potrebno je koristiti druge metode. Bilo bi poželjno uvjeriti adresata da u svakoj nesreći ima i prednosti jer nesreća može biti prilika za razvoj ličnosti. Također bi valjalo podsjetiti adresata da i drugi ljudi pate i da patnju dijelimo s cijelim čovječanstvom te ga podsjetiti na njegovu prijašnju mentalnu izdržljivost, znanje i plemenit karakter. Pismo se zaključuje nuđenjem pomoći adresatu te izražavanjem brige prema njemu i njegovoj obitelji. Šale se u utješnim pismima strogo izbjegavaju te se ne smije činiti kao da umjesto utjehe dijelimo savjete ili naredbe. ${ }^{27}$

Niger dijeli konzolaciju na tri vrste ovisno o nevolji koja je snašla adresata, pa tako razlikuje konzolaciju povodom nepravde, progonstva i gubitka odnosno lišavanja od nečega. Konzolacija uključuje gubitak nekog objekta, neke bliske osobe ili časti. Prema Nigeru utješno pismo sadrži tri dijela. U prvome dijelu izražavamo svoju bol, u drugome pružamo dva, tri ili više razloga na temelju kojih pokazujemo da ne treba tugovati i da treba prekinuti sa žaljenjem, a u trećemu nastojimo adresatu pokazati da su današnje nesreće buduća dobra te nudimo pomoć i potporu adresatu i njegovoj obitelji. ${ }^{28}$

\footnotetext{
${ }^{26}$ Cytowska 1999: 61.

${ }^{27}$ Usp. von Roterdam 1980: 191-201.

${ }^{28}$ Usp. Niger 1572: 19-21.
} 


\section{Vrančićeva konzolacijska pisma}

\subsection{Korpus}

U Vrančićevoj su korespondenciji sačuvana dva pisma koja je uputio Mlečaninu Francescu Capellu 1547. godine te četiri Poljaku Ivanu Boneru (1544., 1548. i dva iz 1549. godine). Autografi pisama čuvaju se u budimpeštanskoj knjižnici Széchényi. ${ }^{29}$ Oba su adresata bili Vrančićevi prijatelji, što se može zaključiti iz sačuvane korespondencije. U tom se korpusu nalaze dva utješna pisma koja je Vrančić uputio Francescu i Ivanu povodom smrti njihovih očeva, Carla Capella (1492.-1546.) i Severina Bonera (1485.-1549.). O Francescu Capellu nije se pronašlo mnogo biografskih podatka, osim da je bio sin Carla Cappella, rođena od Francesca di Cristofora i Elene Priuli di Piero u patricijskoj venecijanskoj obitelji. ${ }^{30}$

Ivan Boner (1516.-1562.) rođen je u Krakovu od Severina Bonera i Sofije Bethmann. Godine 1531. otac ga je poslao u Njemačku pod skrbništvo šleskog humaniste Anselma Eforina. Upravitelj Auschwitza postaje 1546 . godine, potom Chelma 1552. godine, a 1555. promaknut je za upravitelja Biecza. Bio je sljedbenik i promicatelj kalvinizma u Krakovu i Maloj Poljskoj. ${ }^{31}$ U nastavku se donosi kratak sadržaj i analiza dvaju Vrančićevih utješnih pisama. ${ }^{32}$

\subsection{Pismo Francescu Capellu, 15. lipnja 1547. godine}

\subsubsection{Kratak sadržaj pisma}

Vrančić na početku pisma ističe svoju potresenost zbog smrti Capellova oca Carla te uvjerava prijatelja da trenutačno proživljava isto što i on i njegova obitelj. Tu tvrdnju obrazlaže činjenicom da je po-

${ }^{29}$ Rukopisi se nalaze u knjižnici pod signaturom Fol. Lat. 1681. O točnoj lokaciji rukopisa vidi Sorić i Lončar 2017: 85; 143.

${ }^{30}$ Carlo Capello se nakon humanističkog obrazovanja posvetio politici i diplomaciji, a o njegovim književnim interesima svjedoči nekoliko njegovih soneta u čast Veronike Gambare, epigrami povodom smrti voljene žene Serene Loredari di Paolo 1531., kao i govor na latinskome jeziku održan na svečanom sprovodnom slavlju za Giorgia Cornara. Kratki kompendij na latinskom jeziku o pseudoapostolskim konstitucijama De observanda et secundum Deum colenda divina ecclesiastica maiestate, ex Sanctorum Apostolorum constitutionibus et decretis posvetio je Pavlu III. Geneolozi mu pripisuju također dva izgubljena dijaloga: De varietate scientiarum i De vera et perfecta philosophia christiano homine digna. Kod njemačkog cara Ferdinanda I. povjerena mu je 1535. diplomatska misija s ciljem poboljšanja odnosa između dviju država radi potrebe suočavanja s napadom Turaka. Car mu je dodijelio titulu viteza 1538. Za namjesnika Cipra izabran je 1545., a na istom otoku je i umro 8. lipnja 1546. Imao je petero sinova: Piera, Lorenza, Paola, Francesca i Alvisa te dvije kćeri. O Carlu Capellu vidi više: https://www.treccani.it/enciclopedia/carlo-cappello_\%28Dizionario-Biografico\%29/

${ }^{31}$ Deutscher 1985: 166-167.

${ }^{32}$ Pisma su inače objavljena u ediciji László Szalay, Gusztáv Wenzel, edd., Monumenta Hungariae historica. Scriptores, kao Verancsics Antal, Összes munkái, sv. 1-12 (Budapest: Eggenberger, 1857-1875) unutar 6. sveska (Scriptores 9), str. 259-263 i 337338 . 
kojnika dobro poznavao te da je s njim imao prisan odnos. Iz pisma se može zaključiti da je Vrančić bio čest gost u domu Capellovih, odnosno da je bio njihov obiteljski prijatelj. Vrančić potom iznosi svoje stajalište o boli i tugovanju te želi pomiriti dva oprečna stanja: dostojno oplakivanje zbog gubitka voljene osobe i mirno prihvaćanje tog istog gubitka. Nastojeći uvjeriti adresata da prihvati nastalu situaciju, Vrančić navodi što bi on sam i ostali ljudi učinili da moraju utješiti prijatelja u tuzi. Nakon početne faze potištenosti i oplakivanja prihvatili bi zakon smrtnosti, kojemu smo svi podložni te bi nakon toga smogli snage utješiti svoje bližnje pogođene istom nesrećom. Vrančić želi da tako postupi i sam Francesco. Zatim hvali njegove vrline i želi da on sam odluči do kada će tugovati jer smatra da je trajanje tugovanja individualno. Ne želi da bude pasivni promatrač i da se u ublažavanju svoje boli potpuno osloni na vrijeme, već da aktivnim i svjesnim zalaganjem pristupi ublažavanju i prevladavanju boli. Zatim ga podsjeća na općepoznate činjenice o utjecaju vremena i oslanjanju na sudbinu i okolnosti. Po sredini pisma direktno se obraća Francescu prisnim riječima. Govori mu da se prisjeti vrlina svoga oca koje zatim nabraja i iscrpno opisuje. U tim pohvalnim rečenicama vidljivo je Vrančićevo poštovanje i divljenje prema Francescovu ocu. Potom hvali Capellovo gostoprimstvo i velikodušnost koje je doživio tijekom boravka u njegovu domu. Pohvaljuje njegove vrline i sposobnosti upravljanja državom, nastojeći ih povezati s očevima. Time mu želi pokazati kako je sličan svome ocu i da treba biti ponosan na to. Na kraju pisma osvrće se na brodolom Capellove braće. Vrančić izražava žaljenje, ali i ljutnju zbog tog događaja, koji se poklopio sa smrću Francescova oca. Ipak, kako u svakoj nevolji ima i nečeg dobroga, tako i Vrančić ističe da je, unatoč materijalnom gubitku, najvažnije što su braća preživjela brodolom, a materijalna se bogatstva mogu nadoknaditi. U zaključku pisma još jednom ponavlja da Capello i njegova braća trebaju dati sve od sebe da dostojno nasljeduju svog oca te da će zbog toga sigurno biti nagrađeni i priznati, kao što je to bio i njihov otac.

\subsubsection{Analiza pisma}

U pismu Francescu Capellu nalazimo nekoliko konzolacijskih toposa. Na početku pisma Vrančić spominje neizbježnost smrti i važnost njezinog mirnog prihvaćanja jer je ona zajednička svim ljudima:

communes omnium mortalium decędendi leges aequiore animo suadebimus esse tolerandas.

Smrtnost je nešto s čime se rađamo pa je trebamo kao takvu i prihvatiti:

Si enim et charissimo et optimo parente priuatus es, ut es etiam praestanti, scito fuisse mortalem.

Budući da je smrt prirodna pojava, a život nam je dan na ograničeno vrijeme, Vrančić kaže da dijelove naše osobnosti pogođene boli 
zbog gubitka bliske osobe trebamo predati prirodi, jer ćemo na taj način moći lakše nastaviti sa svakodnevnim životom:

et naturae, qua docemur, quam sit dura rerum charissimarum priuatio, partes suas dederimus, eosdem, inquam, quorum peculiare vulnus est ...

Osim toga, smatra da je dužnost sinova dostojno oplakati oca, čime se trenutačno može ublažiti velika bol:

diutius etiam deplorari ac desiderari filiis debet ...

Francescu i njegovoj braći ostaju uspomene na zajedničke trenutke s ocem, a nakon što se umanji tuga i ublaži bol, ostat će ugodne uspomene, koje će im uvijek pružati zadovoljstvo:

eorum memoria, abstersis tandem lachrymis, laetus cum tuis fratribus perfruare, ...

Što se tiče utjecaja Erazmova i Nigerova priručnika, uočeno je da po sadržaju i tonu pisma Vrančić većinom koristi Erazmov indirektni pristup s elementima direktnog. Naime, iako zna da je njegov prijatelj pogođen velikom tugom, ne ustručava od njega zahtijevati staloženost i pribranost te ga isticanjem životnih zakonitosti želi podsjetiti na snagu i razboritost koje posjeduje, a koje je zbog boli možda potisnuo i zanemario. Govoreći mu da sam odredi koliko dugo je razumno tugovati, izražava vjeru da će Capello ispravno postupiti i da će uspjeti prevladati bol:

expendas tecum, velim, ac tute iudices, quamdiu his affectibus viro sit indulgendum, ...

S obzirom na to da trebamo koristiti naše vlastite unutarnje snage pri suočavanju s nevoljama jer je oslanjanje na vanjske faktore, poput vremena, pokazatelj slabog karaktera, Vrančić podsjeća Francesca na moralne vrijednosti $\mathrm{i}$ dužnosti te mu govori da bi bilo nedolično unedogled oplakivati oca:

indignum et te et ipso patre tuo faceres, si laudem hanc non virtuti ac rationi dares, neque eum deflere desineres, ...

Nigerov je utjecaj vidljiv u tročlanoj strukturi Vrančićeva pisma, kakvu nalazimo u uputama priručnika. ${ }^{33} \mathrm{U}$ prvome dijelu pisma Vrančić preuzima bol na sebe, odnosno ukazuje koliko je i sam tužan zbog smrti njegova oca:

De obitu patris tui Caroli, viri praeclari atque optimi nuncio, quem ex tuis litteris intellexi, non aliter, mihi crede, affectus sum, quam quivis vestrum, qui ex eo procreati estis.

U drugom dijelu tješi adresata nabrajajući vrline kojima je bio obdaren njegov otac i zbog kojih može biti ponosan te ne treba odviše tugovati:

${ }^{33}$ Usp. Sorić 2017: 3-4 
Sed ne te, lento gradu auocans a merore, diutius in merore detineam, dum serius ad medullam consolationis accedo, queso te, mi Capelle, proponas tibi ob oculos praestantissimi patris tui virtutes, quibus ille in ista vestra republica, quamdiu vixit, semper cum summa gloria floruit. Mores enim habuit iucundos, graues et magna dignitate conspicuos. Ille et vir et orator bonus, ille acutus philosophus, ille subtilis ac verax theologus, et ne ennarrem singula, ...

Kao treći element pisma nalazimo Vrančićevo iskazivanje nade Capellu u bolju budućnost, upravo kako Niger savjetuje, a ključan je utješni motiv pokojnikova slava, koja će biti trajni spomen na njega, iako on više nije fizički prisutan. Vrančić poručuje Capellu da uvijek ima na umu očeve vrline te da ih i on preuzme jer tako održava sjećanje na njega:

Laus itaque hec magna, Capelle, profecto est, et maiorem in modum celebris. Sed maior ex ea vobis petenda est consolatio... Ea tamen tibi, caeterisque posteris suis de se reliquit monimenta, quae quum sint immortalia et gloria digna sempiterna, eorum memoria, abstersis tandem lachrymis, laetus cum tuis fratribus perfruare,...

\subsection{Pismo Ivanu Boneru, 14. kolovoza 1549. godine}

\subsubsection{Kratak sadržaj pisma}

Na početku pisma Vrančić se ispričava što je prilično zakasnio $s$ izražavanjem sućuti jer mu je kasno stigla vijest o smrti njegova oca. U nastavku govori da ga je to veoma pogodilo i da će ga on dostojno oplakati jer ga je veoma volio i poštovao. Nakon što je iskazao Boneru svoju naklonost i dobre namjere, Vrančić izražava svoje optimistične želje u vezi budućeg života Bonera i njegove obitelji pokazujući iskreno zanimanje za njih. U tome čak pomalo i pretjeruje, pa znajući da takva idealna slika života nije moguća, odmah nastavlja u racionalnijem tonu. Ističe da nijedan čovjek nije u tako povoljnom položaju da bi ga nevolje zaobilazile, tako da mora prihvatiti sve što mu se događa u životu, jer se sve događa s nekim ciljem, odnosno onako kako je Božja providnost odredila. Vrančić ovozemaljski život naziva našim privremenim boravištem, iz kojega odlazimo u naš pravi dom. Zatim mu se obraća molbom da mirno podnese gubitak oca, koji je uz sve svoje odlike bio samo smrtnik. Vrančić smatra da će Boneru najveća utjeha biti vječna slava koju je njegov otac zbog svog uzornog života priskrbio sebi i svojim nasljednicima. Na kraju se s najboljim željama obraća Boneru i njegovoj braći, no zadnje riječi pisma upućuje samome Boneru opominjući ga da ne zanemari svoje poslove. 


\subsubsection{Analiza pisma}

U pismu Boneru također nalazimo više konzolacijskih toposa. Vrančić govori da smrt nije neočekivana jer je ljudski rod od samih početaka podložan različitim događajima i okolnostima, od onih najsretnijih i najpovoljnijih do onih najtežih i najnepoželjnijih:

Atqui quoniam genus humanum non est conditione tam praeclara, et laetis tristibusque, uti aut haec aut illa obvenerint...

Spominje dušu Bonerova oca te iskazuje vjeru u vječni život u koji ne sumnja:

Igitur quiescat in pace sanctissima eius anima et fruatur Christo suo, quem hic adhuc ita induerat, ut nondum carnis velamento deposito in cęlestibus versaretur.

Bonerov je otac također za života doživio veliki ugled i slavu, tako da će njegovo ime ostati zauvijek upamćeno:

quod multos in multis regnis conturbari obitu eius ob raras virtutes ac dotes, quibus in extremi etiam orbis partibus celeberrime noscebatur...

Daje adresatu svoju podršku i ohrabrenje uvjeravajući ga da su pred njim još mnoge lijepe stvari te da je njegov otac sada spokojan i da zasluženo uživa na nebu. Izbjegava moralne pouke i želi da Bonero ima u vidu Božju providnost, po kojoj se sve u životu i u prirodi odvija:

pro divinae providentiae et sapientiae ordinatione vtendum est ...

U pismu nalazimo i elemente koji se preklapaju s Nigerovim uputama za pisanje konzolacijskih pisama, što se prije svega odnosi na već spomenutu tročlanu kompoziciju. Vrančić na samome početku pisma govori o vlastitoj tuzi koju osjeća zbog smrti Ivanova oca:

Quem quidem dolorem etsi mihi non parem, neque tantum usurpem, quantus est filiorum, tamen in deflendo homine mihi benevolentissimo et prope altero parente nulli amicorum eius concessero.

U drugoj kompozicijskoj cjelini nastoji utješiti Bonera na način da spominje kako je njegov otac za života doživio veliki ugled i slavu čime će njegovo ime ostati zauvijek upamćeno. Poručuje mu da je njegov otac postao „besmrtan“ jer su slava koju je stekao kao i sjećanje na njega vječni. Također koristi i motiv smrtnosti, ne da bi ga upozorio na tu životnu istinu, već da bi mu pokazao koliko je njegov otac tijekom svog života postigao, iako je kao smrtnik imao ograničeno vrijeme za to:

oro te, feras aequius charissimi parentis casum, eaque re potissimum consoleris, quod quum ille mortalis fuerit natus, immortalem gloriam suis, sibi nomen atque memoriam compararit, 
quodque in terris ita vixerit, ut in coelis Deo quoque gratissimum civem esse vel ex eo dubitare non debemus, quod multos in multis regnis conturbari obitu eius ob raras virtutes ac dotes, quibus in extremi etiam orbis partibus celeberrime noscebatur, facile mihi persuadeo.

Na kraju pisma ne želi nipošto uvećati Bonerovu nesreću, već ju želi ublažiti optimističnim pogledom u budućnost i vječnim životom kojeg uživa Bonerov otac. I konačno, poziva Bonera da se ne prepusti tugovanju te da ne zanemari svoje dužnosti:

Tibi ac tuis fratribus, ut generis facultatumque, quas vobis maior quam privatus reliquit, illius sitis successores, ita et virtutum et nominis et glorie felicitatumque omnium, quae illi maxime non defuerunt, firmam atque diutinam praecor hereditatem... quod munus ne praetereas, tametsi gravissimo luctu occupatus, etiam atque etiam rogo.

\section{Zaključak}

Konzolacijska je tematika zaokupljala ljude, posebice filozofe, od najranijih vremena. Smrtnost kao jedna od glavnih karakteristika ljudskog roda bila je i još je uvijek predmet promišljanja i proučavanja. Poseban izazov predstavlja suočavanje s njom i mirno prihvaćanje njezine neminovnosti. Smrt bliske osobe neizbježno uzrokuje patnju i bol, no o pojedincu ovisi kako će se s njima nositi. Pružanje utjehe i podrške ožalošćenoj osobi odraz je ljudske humanosti i spoznaje da svi dijelimo istu sudbinu, odnosno da je svačiji život prolazan i vremenski ograničen. Različiti su se filozofski pravci bavili temom utjehe te su zastupali različite metode za ublažavanje boli i davanje moralne $\mathrm{i}$ duhovne potpore pojedincu kako bi mogao što prije nastaviti normalno živjeti. Autori konzolacijskih tekstova iz različitih razdoblja najčešće su posezali za argumentima koje su zastupali stoici, među koje se ubrajaju Ciceron i Seneka.

Konzolacijski su tekstovi postigli osobito snažan dojam u pismima, budući da oblik pisma omogućuje osobniji i iskreniji pristup. Konzolacijska pisma su mješavina filozofije, retorike i književnosti, a glavne karakteristike su im kratkoća i jednostavnost. U obzir se mora uzeti i osobnost te potrebe adresata, prema kojima se oblikuje struktura konzolacijskog teksta. Glavni utješni argumenti razvili su se još u antičko vrijeme, a pojavom kršćanstva došlo je do njihove preobrazbe. Neki argumenti poput besmrtnosti duše i vječnog života su tek u kršćanstvu zadobili svoj pravi smisao. Autori u srednjem vijeku te u doba humanizma i renesanse koristili su antičke postavke i prilagođavali ih s obzirom na društvene okolnosti svog vremena.

U radu su analizirana dva utješna pisma hrvatskoga humanista Antuna Vrančića, koja je povodom smrti njihovih očeva uputio dvojici 
prijatelja, Mlečaninu Francescu Capellu 1547. godine i Poljaku Ivanu Boneru 1549. godine. Oba se pisma u Vrančićevu autografu čuvaju u budimpeštanskoj knjižnici Széchényi. Njihovo se kritičko izdanje donosi u Prilogu na kraju rada. S Capellom i Bonerom Vrančić je inače razmijenio svega nekoliko pisama, međutim iz tog relativno malog korpusa može se uočiti da je s obojicom imao prijateljski odnos. Stoga ne čudi što im je uputio pisma, u kojima ne samo da izražava svoju sućut zbog smrti njihovih očeva, već ih kao pravi prijatelj nastoji utješiti. Vrančić se za oblikovanje svojih utješnih pisama koristi tradicionalnom konzolacijskom topikom te humanističkim epistolografskim priručnicima, koji su bili aktualni u njegovo vrijeme. To su priručnici Erazma Roterdamskog, koji je bio veliki humanistički autoritet te Franje Nigera, čiji je priručnik bio vrlo popularan zbog svoje jednostavnosti. Oba su pisma prilagođena adresatu, koje Vrančić vrlo dobro poznaje te se razlikuju kako dužinom, tako i drukčijim pristupom, premda je sama formalna struktura identična. Erazmo je u svom priručniku definirao tri različita pristupa utjesi i čini se da je Vrančić prihvatio te smjernice, jer ne upotrebljava isti ton i način obraćanja u oba pisma. Erazmo je također postavio više utješnih argumenata od Nigera, pa primjena svih njegovih argumenata utječe na fleksibilnost pisma. Nigerove se početne i završne teze podudaraju s Erazmovim, no u središnjem dijelu daje autorima konzolacije određenu slobodu, ne precizirajući razloge koji bi se trebali upotrijebiti da bi se ožalošćeni odvratio od tugovanja. Može se zaključiti da se Vrančić koristio Nigerovim tezama uz primjenu Erazmova stajališta o prilagodbi načina tješenja ovisno o adresatu. Vrančićev glavni utješni argument $u$ oba pisma je ljudska smrtnost kojoj suprotstavlja pokojnikovu vječnu slavu, koju je zaslužio zbog časnog života. Na taj način čovjek simbolično „pobjeđuje" smrt, jer ostaje duhovno prisutan preko svojih djela i potomaka. 
so.

\section{Ant. SWran. Francisco capillo pricio virnito os:}

Do obit $n$ patsis tmi Caroli, vivi prad clari, atgs options micis, quim Ex tris lis intrill'xis, nó at mith crreds, affritur su' ig' quivis Vvim, gus ace so pro. corrati effis. Sxice id guidim sin' insta róms. Am avit ins! me, it complixus rst simp, nor ut quimpia' faniliar!. "us amias hoirm, sed ut propingus, stem, ant nuirs from. guar si sir naidisfie, ut vobis gramisfió, "at furvestissio isto ca/u v'o doßs, potuiss"', iusx esser saní Larbyymis vés flutus mios,

Slika 1. Početak Vrančićeva pisma Francescu Capellu, Fol. Lat. 1681/1, 230v 
An.wr.Jo. Gonavo.s.

$32 \$ 4$.

P atren tur optimu' at clavisimi vivis

$\varepsilon$ vivis "xcessisspl, mun primum saure ad mov perlatí, intollsox; , plurinn't dolco, q tam siró . Vi drbar sinim in hoc officio dreta

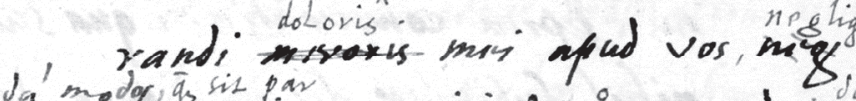

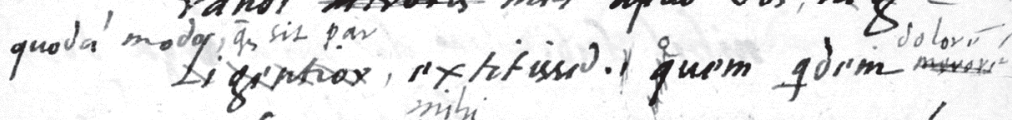

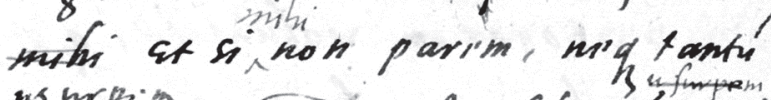

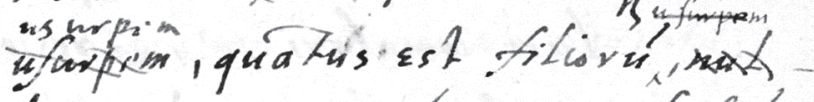

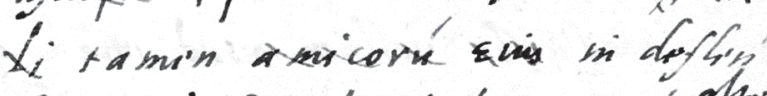

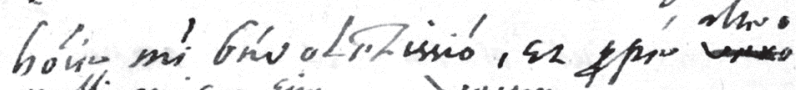

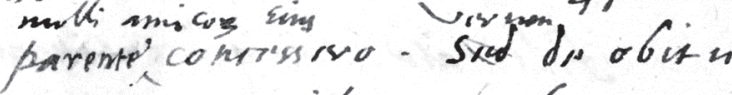
enis, qui ocim raxit bonorum, $\mathrm{cmm}$.

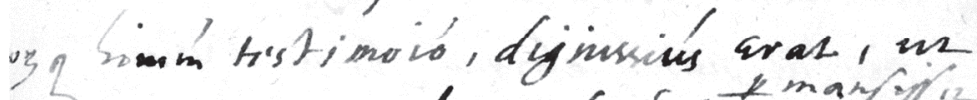

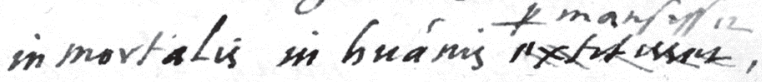
noto dolovis huvis mas in

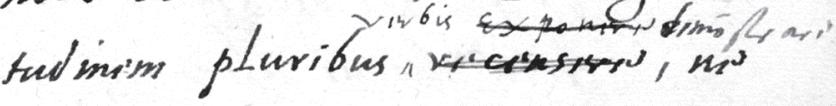

\section{1}

Slika 2. Početak Vrančićeva pisma Ivanu Boneru, Fol. Lat. 1681/1, 324r 


\section{BIBLIOGRAFIJA}

\section{IZVORI:}

Országos Széchényi Könyvtár, Budimpešta - Fol. Lat. 1681/1, 230v-237r i 324r-326v.

\section{LITERATURA:}

Brannen, Charles J. 1948. A Study of the Origins of Cicero's Consolatory Writings and Their Effectiveness in the Author's Own Life. URL: http://ecommons.luc.edu/luc theses/64 (13.srpnja 2021.).

Crepajac, Ljubomir. 1974. „Predgovor“. U: Ciceron (1974): Rasprave u Tuskulu. Beograd: Srpska književna zadruga.

Cytowska, Maria. 1999. „Źródła staropolskiej wiedzy retorycznej”. U: Źródła wiedzy teoretycznoliterackiej w dawnej Polsce, Średniowiecze - Renesans - Barok, ur. Maria Cytowska and Teresa Michałowska, 61, Warszawa.

Deutscher, Thomas B. 1985. Contemporaries of Erasmus. A Biographical Register of the Renaissance and Reformation, vol. 1-3. Toronto - Buffalo -London: University of Toronto Press.

Henderson, Judith R. 2007. „Humanism and the Humanities: Erasmus's Opus de conscribendis epistolis in Sixteenth-Century Scools", Letter-Writing Manuals and Instruction from Antiquity to the Present, ur. Poster C. and Linda C. Mitchell L. C The University of South Carolina Press, South Carolina, 141-177.

Jurić, Šime. 1975. „Humanist Franjo Niger“, Senjski zbornik: prilozi za geografiju, etnologiju, gospodarstvo, povijest i kulturu, 6, 1, 285-296.

Moran, Mary Evaristus. 1917. The consolations of death in ancient Greek literature. URL: http://www.24grammata.com/wp-content/uploads/2014/08/The-Consolations-ofDeath-n-ancient-greek-literature.pdf (13. srpnja 2021.).

Niger, Franciscus. 1572. Francisci Nigri 'De conscribendis epistolis' tractatio, Venetiis: Apud Altobellum Salicatium.

Schaeben, Ulrike. 2002. Trauer im humanistischen Dialog: Das Trostgespräch des Giannozzo Manetti und seine Quellen. Berlin: de Gruyter.

Sorić, Diana. 2017. „Antun Vrančić's „Occasional” Letters in the Light of the Humanistic Treatises of Letter-Writing", Systasis e-journal of the Association of Classical Philologists "Antika” 30, Skoplje: Antika, 1-8.

Sorić, Diana i Lončar, Milenko. 2017. „Rukopisi Antuna Vrančića (Fol. Lat. 1681.) iz knjižnice Széchényi u Budimpešti”, Zbornik Odsjeka za povijesne znanosti Zavoda za povijesne i društvene znanosti HAZU 35, Zagreb: HAZU, 85-143.

Tworek, Michael. 2004. Orszula's Death: Grief and Consolation in the Renaissance - The Treny of Jan Kochanowski. History Honors Theses. Paper 2, 2004, 27-34, URL: http://digitalcommons.trinity.edu/hist_honors/2 (10. svibnja 2021.).

Von Moos, Peter. 1971. Consolatio: Studien zur mittellateinischen Trostliteratur über den Tod und zum Problem der christlichen Trauer. Bd. 1. München: Wilhelm Fink Verlag. URL: https://www.digitale-sammlungen.de/ (11. svibnja 2021.).

Von Rotterdam, Erasmus. 1980. De conscribendis epistolis, Anleitung zum Briefschreiben, Wissenschaftliche Buchgesellschaft, Darmstadt.

Zimmermann, Bernhard. 2008. „Philosophie als Lebenshilfe: Die griechisch-römische Consolationsliteratur“. URL: http://www.lexisonline.eu/wordpress/?page_id=730 (1. srpnja 2021.). 
Diana SORIĆ

Maja CIFREK

\section{TWO CONSOLATORY LETTERS BY ANTUN VRANČIĆ - summary -}

The consolatio refers to a text written immediately after one's death, addressed to one or more addressees, in order to allievate or overcome the pain. Rhetoric and various philosophical directions had a significant impact on the consoling, and the emergence of Christinity brought about the joining of Christian and Pagan motives. The comforting letters were very popular in the period of humanism and their authors often resorted to antique motifs. The backbone of this work are two comforting letters by Antun Vrančić (1504-1573), which he sent to two of his friends, the Venetian Francesco Capello and the Pole John Boner. In an attempt to show the interplay of consolation arguments, Vrančić used the traditional consolation themes to form his comfort letters, as well as the possible influence of two epistolographical manuals by Erasmus of Rotterdam (1469-1536) and Franjo Niger (1452-?). Erasmus defined three different approaches in his manual and it seems that Vrančić accepted these guidelines because he did not use the same tone and way of speaking in both of his letters. Erasmus also put forward more comforting arguments than Niger did, so the application of all his arguments affected the flexibility of the letter. Niger's initial and final thesis coincide with those of Erasmus, but the author gave the central consolation part some freedom, not specifying the reasons that should have been used to distract the mourners from grieving. It can be assumed that Vrančić used Niger's thesis with Erasmus' approach of adjusting the comforting ways depending on the addressee. Vrančić's main consoling argument in both letters is that human mortality opposes the eternal glory of the deceased, which he deserves because of his honorable life. In this way, man symbolically "wins" over death because he remains spiritually present through his works and descendants.

Key words: consolation, Antun Vrančić, consolatory letters, Erasmus of Rotterdam, Franciscus Niger. 


\section{PRILOG}

\section{Kritičko izdanje pisama ${ }^{1}$}

\section{0v/ Antonius Wrancius Francisco Capello patricio Veneto salutem ${ }^{2}$}

De obitu patris tui Caroli viri praeclari atque optimi nuncio, quem ex tuis litteris intellexi, non aliter, mihi crede, affectus sum quam quivis vestrum, qui ex eo procreati estis. Nec id quidem sine iusta ratione. Amauit enim me et complexus est semper, non ut quempiam familiarem et amicum hominem, sed ut propinquum suum, aut unicum fratrem. Quare si sic accidisset, ut vobis grauissimo et funestissimo isto casu vestro adesse potuissem, iunxissem sane lachrymis vestris fletus meos, /231/ nec luctus vestri tempus non attratus exegissem, ut, cum quibus complures sepenumero dies summa festivitate ac leticia habuerim, iis in merore constitutis, meum tum merorem, tum dolorem non denegassem. Verum quamquam acerbissimus dolor est, qui ex amissione parentis nascatur, isque parens, qui et suis insigni pietate praefuit et reipublicae suę, in qua natus erat, per omnem vitam praestantissimae virtutis operibus ac magnitudine laborum profuit, diutius etiam deplorari ac desiderari filiis debet, tamen amici nos ut $/ \mathbf{2 3 1}$ / fungamur officio verae amicitiae, nosque etiam homines esse meminerimus, non indigne faciemus, si, postquam aliquandiu vna cum amicis fleuerimus, et naturae, qua docemur, quam sit dura rerum charissimarum priuatio, partes suas dederimus, eosdem, inquam, quorum peculiare vulnus est, curabimus ad consolationem reuocandos, atque eis demonstrata humanitatis nostrae conditionae, communes omnium mortalium decędendi leges aequiore animo suadebimus esse tolerandas. Quapropter quum non ignoro, te ab ipsa usque adolescentia sub discip/232/lina doctissimi patris fuisse et moderationis et prudentię et fortitudinis semper studiosum, expendas tecum, velim, ac tute iudices, quamdiu his affectibus viro sit indulgendum, qui et haberi uult, quem profitetur et iudicio sapientis, non uulgi superstitione ducatur. Neque ullo modo committas, ut ipso

\footnotetext{
${ }^{1}$ Načela izdanja: U ovim se autografskim pismima autorski zapis u potpunosti poštuje, osim u sljedećim slučajevima: grafija tzv. $i$ longa zamijenjena je znakom $i$, moderniziralo se pisanje velikoga i maloga slova te interpunkcija radi lakšeg praćenja teksta, a ispravile su se i evidentne pogreške u pisanju (npr. susperstitione se ispravilo u superstitione). Sve su se kratice u izvorniku razriješile bez upozorenja. Kratica S-W = László Szalay, Gusztáv Wenzel, edd., Monumenta Hungariae historica. Scriptores - Verancsics Antal, Összes munkái, sv. 1-12 (Budapest: Eggenberger, 1857-1875)

${ }^{2}$ Oba su pisma priređena prema rukopisima iz knjižnice Széchényi u Budimpešti: Fol. Lat. 1681/1, 230v-237r i $324 \mathrm{r}-326 \mathrm{v}$.
}

16 amici nos ut ] ita 
temporis decursu dolorem deponas. Hoc enim et odia hominum maxima sine conciliatore sepe uidimus deleuisse et aegritudines ademisse sine omni usu medicinarum. Unde inniti tempori, opperiri casus et a fortuna pendere, quae $/ 232 \mathrm{v} / \mathrm{ut}$ interdum stultis etiam apprime suffragentur atque inseruiant, ita et sordidos et indignos efferre consueuerunt, ignauorum hominum esse

5 prodiderunt sapientes. At tu, qui admodum sane iuvenis, et quidem eo ipso tempore, quo virilem togam sumpseras et praeturas inire inceperas, non obscuram sane de se senatui tuo, vel me inter caeteros non omnium minimo teste, qui tum legatione in vestra civitate fungebar, spem excitasti, indignum et te et ipso patre tuo /233/ faceres, si laudem hanc non virtuti ac rationi dares, neque eum deflere desineres, quem eadem lege, qua praemisisti, non multo post,

10 tametsi post annum LXX., sequeris, quum omnia tum orta, tum oritura occidant et aucta senescant. Sed ne te, lento gradu auocans a merore, diutius in merore detineam, dum serius ad medullam consolationis accedo, queso te, mi Capelle, proponas tibi ob oculos praestantissimi patris tui virtutes, quibus ille in ista vestra republica, quamdiu vixit, semper cum summa gloria floruit. Mores enim habuit iucundos, graues et magna dignitate conspicuos. Ille et vir et orator $/ 233 \mathrm{v} /$ bonus, ille acutus philosophus, ille subtilis ac verax theologus, et ne ennarrem singula, in omnibus ille VII. liberalibus artibus fuit sane consumatissimus. Trium vero linguarum eruditionem ita erat consequutus, ut Haebraice, Graece ac Latine et scriberet et loqueretur, idque adeo facile et expedite, ut cum iis natus esse videretur. Ingenio autem atque animi praestantia, qua pollebat in gerendis rebus, plurimae legationes et nouorum insignium ac titulorum equestris dignitatis, /234/ quae iam familiae tuę potest esse hereditaria, testantur accessiones. Quanta ad hec vixerit aequitate, quanta vbique gesserit sese moderatione atque integritate, prouinciae quibus praefuit, palam et cum laude loquuntur. Nec postremo fidem atque consilium eius vrbani magistratus et defensiones clientum non extollunt, quum et senatorius ordo, ut mihi nunciatur, eum tanquam Valerium quendam Publicolam suum communi totius ciuitatis lamentatione desiderauit. Multa hic alia ornamenta, variaeque dotes nobilissimi parentis tui recenseri possent, quibus ille et $\mathrm{ma} / \mathbf{2 3 4}$ /iores suos aequauit, et vobis iunioribus suis praebuit lumen, quo eorum claritudinem non imitari solum, sed etiam assequi atque augere possitis, nisi a ratione epistolae in orationem rerum grauitate delabi pertimescerem. Concludam itaque paucis. Anno enim superiore, quo praetor eras Muriani, quum essem ego apud te et egregie ac magna cum voluptate frueremur vna genio, ubi mihi,

6 post se del. et magnitudini 9-10 non ... tametsi ] sscr. 10 post... LXX. ] in marg. 10-11 et... senescant ] in marg. 11 lento gradu ] sscr. $12 \mathrm{mi}$ ] sscr. $\mathbf{1 5}$ subtilis ] sublimis S-W 17 consecuutus ] consecuutas S-W 21 moderatione atque ] sscr. 
quae tua erat humanitas, atque gratia, nihil tecum ac cum tuis non licebat, tuque in summis solatiis et animi remissione summa sedulitate, qui/235/eti atque concordiae ciuitatis eius reparandae et constituendae intentissima cura atque studio satageres, plane perspexi, quanti erat parens tuus apud Venetos patricios, cuius respectu, omnes te his in rebus occupatum, non

5 aliter excipiebant, audiebant, absoluebant, quam si vnicuique aut filius esses, aut iam maxima in patriam beneficia contulisses et de singulis pręclarissime meruisses. Laus itaque hec magna, Capelle, profecto est et maiorem in modum celebris. Sed maior ex ea vobis petenda est consolatio. $\mathrm{Si}$ enim et charissimo et optimo parente priuatus es, ut es $/ \mathbf{2 3 5} \mathrm{v} /$ etiam praestanti, scito fuisse mortalem. Ea tamen tibi, caeterisque posteris suis de se reliquit

10 monimenta, quae quum sint immortalia et gloria digna sempiterna, eorum memoria abstersis tandem lachrymis laetus cum tuis fratribus perfruare, simulque, ut iam vos quoque patres esse possitis, nauate operam et contendatis, ut vestrum virtutibus meritisque in rempublicam aequiparetis ac in posterum curetis, ut prudenter leges humanitatis perferatis. De nauffragio autem fratrum et bonis ac supellectile tota in reditu ex Cypro mari atque igni /236/ amissis,

15 itidem equidem atque vos permoleste tuli, execratusque sum casum et fortunam mirifice admiratus, cui non satis fuit patrem vobis eripuisse, nisi et piratas in vos immittendo, aquis bona vestra hauriret partim, partim igni absumeret, ut in vestrum detrimentum ad pernitiem, quam latrones vobis intenderant, duo quoque dissidentissima elementa concordarent. Accidit hoc iuxta tritum infelicium proverbium: Nullum malum solum. Et illud, quod est maius, atque

20 grauius, societate velut tyrannus quidam satellitibus stipatur. Sed gaudendum esse et /236v/ hoc aliud fortunę telum leuius tibi puto existimandum, postquam ex eodem naufragio, quod cum bonis fratres quoque duos deprehenderat, ambo ipsi fratres euaserint. Vita enim superstite non deerunt opes, haeque quamquam saepius possessorem mutent, viuos tamen sequuntur, nec his homines a morte redimuntur, sed amissae viuis frequenter reparari solent.

25 Quare operam date diligenter, ut patris mores ac vitam aemulantes, valetudini primum, deinde reipublicae vestrae studeatis. Quae duo si pro viribus vestris praestiteritis, /237/ aderit certe et sanis ad acquirendum facilitas, et patriae decori, commodoque seruientibus digna beneficiorum honorumque non decrit compensatio. Petro, Paulo, Laurentio fratribus tuis meo nomine dic salutem; Paulo et Laurentio etiam gratuleris, quod redierint incolumes. Vale. 15. Junii 1547. Ex Transsylvania. Albae Giulae.

13 ac... posterum ] sscr. 17-18 ad pernitiem... intenderant ] sscr. pro ad latronum pernitiem 19 est maius ] mut. ex maius est 25 post mores del. aemulantes 28 Petro, Paulo ] sscr. pro Paulo, Petro 


\section{/324/ Antonius Wrancius Joanni Bonaro salutem}

Patrem tuum optimum et clarissimum virum e vivis excessisse, nunc primum sane ad me perlatum intellexi, plurimumque displicet, quod tam sero. Videbor enim in hoc officio declarandi doloris mei apud vos negligentior quodammodo, quam sit par, extitisse. Quem

5 quidem dolorem etsi mihi non parem, neque tantum usurpem, quantus est filiorum, tamen in deflendo homine mihi benevolentissimo et prope altero parente nulli amicorum eius concessero. Verum de obitu eius, qui omnium bonorum summorumque hominum testimonio dignissimus erat, ut inmortalis in humanis permansisset, nolo doloris huius magnitudinem pluribus verbis demonstrare, ne $/ 324 \mathrm{v} /$ tuo apponere incrementa, tibique tam grave vulnus,

10 quamvis iusta ac debita observantiae meae in eum commemoratione acerbius facerem et quasi renovarem, contentus itaque propria conscientia. Qua scio te nihil dubitare de mea erga domum Bonariam voluntate, quodque non solum consolari te et revocare a luctu vellem, sed etiam quod cupiam, ut et tu et tui omnes tanta felicitate tamque continenti ac diutino rerum successu frueremini, ut nunquam alterius fortunae vultus videretis, nunquam alterius a leticia

15 status vices sentiretis, viveretis alioqui ultra quam cuippiam /325/ hominum etiam beatissimorum natura concesserit. Atqui quoniam genus humanum non est conditione tam praeclara, et laetis tristibusque, uti aut haec aut illa obvenerint, pro divinae providentiae et sapientiae ordinatione vtendum est, donec in patriam ex hac peregrinatione evadamus: oro te, feras aequius charissimi parentis casum, eaque re potissimum consoleris, quod quum ille mortalis fuerit natus, immortalem gloriam suis, sibi nomen atque memoriam compararit, quodque in terris ita vixerit, ut in coelis Deo quoque gratissimum civem esse vel ex eo dubitare non debemus, quod multos $/ \mathbf{3 2 5}$ / in multis regnis conturbari obitu eius ob raras virtutes ac dotes, quibus in extremi etiam orbis partibus celeberrime noscebatur, facile mihi

3 displicet ] sscr. pro doleo 3 post enim sscr. et del. quodammodo negligentior 4 doloris ] sscr. pro meroris $\mathbf{4}$ negligentior... par ] sscr. et in marg. 4 extitisse. Quem ] mut. ex extitisse, quem 5 dolorem ] sscr. pro merorem $\mathbf{5}$ etsi mihi ] mut. ex mihi etsi $\mathbf{5}$ usurpem ] sscr. pro usurpem $\mathbf{5}$ post filiorum sscr. et del. usurpem $\mathbf{5}$ post filiorum del. nulli 5 post tamen del. amicorum eius $\quad 6$ altero ] sscr. pro vero 6 nulli... eius ] sscr. 7 Verum ] sscr. pro Sed 7 post omnium del. sane 7 summorumque hominum ] in marg. 8 permanisset ] sscr. pro extitiset 8 post huius del. mei $\mathbf{9}$ verbis demonstrare ] sscr. pro recensere 9 post verbis del. exponere 9 post ne del. eum ipsum dolorem longius exponendo 9 post tuo del. maiora $\mathbf{1 0}$ observantiae ] sscr. 10 in eum ] sscr. 10 acerbius... quasi ] sscr. 11 contentus ] ita, sed melius esset contentus ero 11 contentus itaque ] mut. ex verum contentus 11 itaque ] sscr. 16 Atqui ] sscr. pro Tamen 17 praeclara ] sscr. pro praestanti 18 evadamus ] sscr. pro euolvamur 20 fuerit natus ] mut. ex natus fuerit 21 Deo ] sscr. 21 post quoque del. Deo atque angelis quam 22 conturbari... eius ] sscr. pro angi eius desiderio 22 post raras del. illius 23 facile ] sscr. pro facilime 
persuadeo. Igitur quiescat in pace sanctissima eius anima et fruatur Christo suo, quem hic adhuc ita induerat, ut nondum carnis velamento deposito in cęlestibus versaretur. Tibi ac tuis fratribus, ut generis facultatumque, quas vobis maior quam privatus reliquit, illius sitis successores, ita et virtutum et nominis et glorię felicitatumque omnium, quae illi maxime non

5 defuerunt, firmam atque diutinam praecor hereditatem. /326/ Stanislavis duobus, alteri Lasco amplissimo Syradiensi palatino, alteri Bonaro fratri tuo nobilissimo iuveni et Anselmo Ephorino cupio maxime commendari; quod munus ne praetereas, tametsi gravissimo luctu occupatus, etiam atque etiam rogo. Vale. XIIII. Augusti 1549. Albae.

1 eius anima ] mut. ex anima eius 3-4 facultatumque... successores ] sscr. et in marg. pro atque operum tanti patris legitimi successores sitis. Heredes sitis tanti patris, sic 6 fratri tuo ] om. S-W 6 nobillisimo iuveni ] sscr. 7 post Ephorino del. medico maxime 7 maxime ] sscr. 7 munus ne praeteras ] mut. ex ne praeteras munus 
